\title{
RESISTENSI AGAMA DAN BUDAYA MASYARAKAT
}

\author{
David Samiyono \\ Universitas Kristen Satya Wacana Salatiga \\ e-mail:d_samiyono@yahoo.com
}

\begin{abstract}
Ethnic group, religion, and cultural interactions are familiar phenomena in Bali. Such an interraction had been there since the island became the locus for trading activities. The concept of Tri hita karana is underlying the harmony on the relations of human beings and God (perhyangan), human beings each others (pawongan) and human beings with the environment (palemahan). Bali is changed now. The culture orientation is on services related to tourism. Bali blast on October 2002 and 2005 effected on the on guard among Baliness. Ajeg Bali is a local wisdom of Baliness -religions and cultures - in order to anticipate outside influences effected toward any aspect of life. The problem in this research is weather Ajeg Bali, as local wisdom able to damm outside culture toward Baliness culture, religion, and economics.

***

Interaksi antar etnis, agama dan budaya bukanlah barang langka di Bali. Sejak semula hal tersebut sudah ada, ketika pulau ini menjadi locus perdagangan hasil bumi. Sebab sesungguhnya kebudayaan Bali menjujung tinggi nilai-nilai keseimbangan dan harmonisasi antar manusia dengan Tuhan (perhyangan), dengan sesama (pawongan) dan dengan lingkungan (palemahan). Konsep ini disebut Tri hita karana. Bali kini berubah. Budayanya berorientasi pada jasa, yang berkait dengan industri pariwisata. Sikap orang Bali kini tidak lagi ramah dan harmoni. Akibat ledakan bom dalam bulan Oktober 2002 dan 2005, masyarakat lebih berhati-hati terhadap para pendatang. Ajeg Bali merupakan kearifan lokal agama dan budaya- masyarakat Bali dalam rangka menanggulangi pengaruh luar yang mengakibatkan perubahan di berbagai bidang sehingga identitas kebalian mengalami degradasi. Ajeg Bali merupakan bentuk resistensi masyarakat Bali dalam rangka membatasi pendatang dari luar Bali. Kajian ini berusaha untuk menjawab pertanyaan "apakah Ajeg Bali, sebuah kearifan lokal masyarakat Bali dapat membendung pengaruh budaya, agama dan ekonomi masyarakat Bali?"
\end{abstract}

Keywords: Bali, pluralisme, harmoni, budaya, Ajeg Bali 


\section{A. Pendahuluan}

Pasca bom Bali pada bulan Oktober 2002 dan Oktober 2005, Bali seakan terpuruk, hati rasanya remuk redam, tidak ada tulang untuk menopang tubuhnya. Industri pariwisata yang menjadi tulang punggung ekonomi pulau Bali hancur lebur. Wisatawan kabur dan takut datang ke pulau yang penuh dengan eksostisme ini. Pemutusan hubungan kerja terjadi dimana-mana. Situasi dan kondisi semcam ini membuat gerah desa adat, desa yang dahulu sepi menjadi ramai, karena penduduknya kembali dari kota, tidak ada pekerjaan lagi di sana. Akhirnya situasi ini menjadikan sifat kekerabatan mereka semakin erat.

Kejadian di atas menjadikan masyarakat Bali menjadi sadar, bahwa tanah air mereka sudah di obok-obok oleh masayarakat pendatang. Kesadaran primordial sebagai Balian menjadi semakin kuat. Sebagai akibatnya maka muncullah beberapa peraturan yang pada intinya membatasi masuknya pendatang dan budaya asing ke Bali. Bali harus kembali kepada agama dan budaya nenek moyang, selanjutnya dikenal dengan sebutan "Ajeg Bali". Tujuan utama dari Ajeg Bali menurut analisis Kiwi adalah dalam rangka desentralisasi regulasi untuk memperkenalkan dan mengelola ekonomi dan budaya daerah. Hal ini tidak sepenuhnya benar karena Ajeg Bali tidak memiliki makna tunggal. Sebab pada tahun 2004, istilah Ajeg Bali digunakan oleh para politikus untuk menarik simpati masyarakat.

Kajian tentang Ajeg Bali dalam artikel ini merupakan bagian kecil dari penelitian mengenai "Menyama Braya" yang dilaksanakan di Bali pada tahun ke dua (1999-2010). Pengambilan data dilakukan melalui participation observation dan depth interview. Wawancara dilakukan dengan beberapa tokoh adat, tokoh masyarakat dan masyarakat di wilayah Denpasar dan Kabupaten Karangasem. Penelitian ini merupakan bentuk Hibah Kompetitif yang diselenggarakan oleh Mendiknas.

Apakah sesungguhnya yang mendasari niat masyarakat Bali untuk kembali membuka wacana Ajeg Bali? Hal ini tidak terlepas dari kondisi sosial, ekonomi dan politik masyarakat Bali. Jika ingin memotret kondisi bali, maka ada dua cara: pertama pergi ke desa-desa di Bali, dengarkan apa yang dipercakapkan oleh masyarakat, potretlah keadaan mereka. Cara kedua, adalah bertanya kepada orang Bali yang sudah tinggal lama di luar pulau Bali. 
Ditanya apa komentarnya mengenai Bali saat ini. Selanjutnya lakukan analisis, dengan tidak melibatkan emosi. Jawaban yang tidak terduga akan muncul, terutama dari orang Bali yang sudah lama tinggal di luar tanah kelahirannya. Bali saat ini sudah kehilangan arah atau Bali dalam keadaan kritis! Mengapa?

Salah satu contohnya adalah tradisi ritual yang selalu dilakukan setiap hari. Pola pikir masyarakat Bali masih terpaku pada pola lama: banten atau sesajen, penyelenggaraan upacara dengan penuh kemewahan, dan jika perlu berhutang. Ritual semacam ini pada masa lalu dapat dilakukan dengan baik, karena masyarakat Bali pada mulanya adalah masyarakat agraris. Hasil pertanian melimpah, sarana dan prasarana untuk banten sangat mudah dan murah didapatkan. Sebaliknya, saat ini masyarakatnya sudah banyak yang beralih profesi menjadi pemandu pariwisata atau berdagang kerajinan, atau menjadi pegawai swalayan. Tanah yang dahulu banyak menghasilkan sumber makanan, sekarang beralih fungsi menjadi hotel dan tempat-tempat wisata. Orang Bali mabuk ketika dipanggil sebagai seniman, membuat mereka tidak mau merambah ke sektor informal, misalnya berdagang, karena malu atau gengsi.

Akibatnya, orang pendatang luar Bali yang mengambil kesempatan. Mereka mendirikan tenda di terminal, membawa rombong atau gerobag keliling desa menjajakan dagangan mereka: jagung rebus, bakso, pecel lele, bebek goreng dan bahkan tidak sedikit yang membuka kafe. Keuntungan pedagang dari luar Bali semakin menumpuk, mereka mampu membeli tanah dan mendirikan rumah di Bali. Sementara itu orang Bali semakin terpuruk oleh keadaan mereka. Mengapa orang Bali tidak mau bekerja di sektor informal? Apakah karena gengsi, sama-sama bekerja sebagai pencuci piring berbeda mencuci di pinggir jalan dengan di hotel? Jika hal itu benar, maka tidak salah jika pemandangan di pinggir-pinggir jalan sektor informal dikuasai oleh pendatang. Tidak tanggung-tanggung, label yang mereka gunakan seperti "Pecel Lele Madiun", "Soto Lamongan", "Siomay Bandung", "Warung Jawa" dan sebagainya.

Di kampung-kampung, masyarakat mudah tergiur oleh ratusan juta rupiah untuk ditukar dengan sawah mereka. Tidak lama kemudian sawah itu berubah fungsi menjadi tampat wisata yang ramai. Sementara uang hasil penjualan sawah sudah dibelikan motor atau barang elektronik yang lain. 
Dua bulan uang itu sudah ludes, tidak tersisa lagi, sementara anak dan istri perlu makanan setiap hari. Akhirnya, ia harus bekerja pada tempat wisata di bekas tanah miliknya.

Pada sisi yang lain, kahadiran kelompok-kelompok pendatang yang mengusung semangat keagamaan dan kebudayaan (selain Hindu dan Budaya Bali) juga ikut andil dalam pergulatan identitas etnis. Sebagai contoh, di sebuah perkampungan Islam, seorang tokoh Islam lebih banyak bicara soal perbedaan dan mempertajam demarkasi antara Islam dan Hindu. Ini bagaikan menumpuk ranting-ranting kering yang selanjutnya mudah dibakar, tinggal menunggu waktu saja. Selain itu, agresifnya pendatang dalam bidang ekonomi dan agama semakin membuat naiknya tensi konflik psikis alam bawah sadar masyrakat lokal. Bali kini beda dengan masa lalu. Bom memang sudah berlalu, pembangunan fisik sudah dilakukan, bahkan lebih baik dari sebelumnya. Namun apakah dampak psikisnya juga sudah pulih?

Keterikatan sosial masyarakat Bali menjadi semakin rapuh manakala beberapa sektor sudah dikuasai oleh pendatang. Mereka perlu introspeksi diri, ingat bahwa leluhur orang Bali pada masa lalu menjaga betul hasil pertanian untuk kepentingan yadnya, baik yadnya berupa piodalan maupun untuk hari besar seperti Galungan. Ternyata saat ini uang bisa mengubah segalanya. Jika pada masa lalu buah dan sayuran dengan mudah dapat dipetik di kebun, sekarang beli buah harus di pasar atau swalayan yang didatangkan dari Jawa. Janur pun sebagai alat utama upacara juga didatangkan dari Banyuwangi, bersama sayur dan bunga.

\section{B. Tantangan yang Dihadapi}

Terjadinya kesenjangan ekonomi diantara masyarakat Bali, masuknya budaya asing dan rendahnya tingkat partisipasi pendidikan khususnya di pedesaan cukup signifikan lebih dari $5 \%$ (Direktorat Pendidikan Sekolah, 2007). Hal ini mengakibatkan kantong-kantong kemiskinan meningkat di beberapa Kabupaten (data Bali Post 12 Juli 2006). Tantangan lain yang dihadapi oleh masyarakat Bali adalah mereka tidak sepenuhnya menjadi tuan rumah di negerinya sendiri. Hal ini nampak dari sektor ekonomi (usaha) tidak dikuasai oleh masyarakat Bali. Mereka biasanya hanya sebagai pramusaji atau pramuniaga atau bahkan tenaga upahan di negerinya sendiri. Pada sektor pariwisata, masyarakat tidak menjadi pemain utama, sebagian hanya 
menjadi penonton. Berbagai permasalahan ini masih ditambah dengan meningkatnya jumlah penduduk, khususnya pendatang yang mengakibatkan penduduk pribumi tersingkir ke wilayah pinggiran. Sementara itu, penetrasi budaya asing melalui investor sekaligus life style-nya, membuat masyarakat Bali bermodel materialistik.

Tantangan yang dihadapi oleh masyarakat Bali tersebut cepat atau lambat akan menciptakan penderitaan masyarakat dan kehancuran Bali, baik di bidang budaya atau agama. Bisa terjadi, Bali bukan lagi "island of paradise", sebaliknya Bali tidak berbeda dengan pulau yang lain di Nusantara ini. Hal tersebut bisa terjadi karena beberapa faktor yang mempengaruhi, di antaranya, rendahnya kesadaran pelaksanaan shrada. Shrada adalah spirit untuk bangkit dan bekerja keras. Pada sisi keagamaan, praktek keagamaan yang disebut yadnya diartikan dalam dimensi yang sempit, hanya upacara saja sebagai bhakti kepada Ida Shang Hyang Widhi Wasa, tanpa pemahaman makna universal, seperti apa hakikat kehidupan dan nature of life sebagai esensi agama yang sebenarnya. Berdasarkan beberapa permasalahan tersebut maka pemerintah Bali, khususnya Denpasar berusaha untuk menyadarkan masyarakatnya melalui kearifan lokal yang disebut dengan Ajeg Bali.

\section{Perubahan Nilai dan Konsep Ajeg Bali}

Di Bali, pada awalnya ada dikotomi sebagai penanda antara pendatang dan orang lokal, yaitu nak Jawa dan nak Bali (orang Bali menyebut semua orang Indonesia lainnya anak Jawa dan semua orang asing tamu). Mungkin pada awalnya istilah ini hanya sebagai penanda yang tidak memiliki makna yang signifikan, kecuali menunjukkan primordialisme masyarakat Bali dan pendatang. Akan tetapi, istilah nak Bali dan nak Jawa sekarang telah bergeser dan melahirkan persoalan struktural yang menyebabkan terjadinya ketegangan relasi antara orang Bali (penduduk lokal) dan pendatang. Dulunya orang Bali menyebut orang Jawa sebagai nyama Jawa (saudara dari Jawa). Saat ini, sebutan itu sudah bergeser menjadi jelema Jawa (orang Jawa). Perbedaan nyama Jawa menunjukkan kedekatan sedangkan jelema Jawa menunjukkan kejauhan. Begitu juga dengan kata nyama Selam (saudara Islam) yang kini bergeser menjadi jelema Selam (orang Islam). 
Perubahan ini, dapat dilihat dari wacana keseharian masyarakat Bali tentang Ajeg Bali. Secara historis tersirat, wacana ini bergema luas sesudah peristiwa pemboman di Kuta yang terjadi 12 Oktober 2002. Sebuah konsep yang dimulai dari inisiatif kelompok media Bali Post, tepatnya pada peresmian Bali TV. Menurut Wijaya (2003) kata Ajeg mula-mula digunakan oleh Ida Pedanda Made Gunung dalam berbagai dharmawacana-nya (khotbah). Ajeg Bali, terdiri dari dua kata Ajeg dan Bali. Kata ajeg secara etimologis berarti berdiri tegak, kokoh, tidak goyah, tidak berubah dalam waktu relatif yang lama. Dengan demikian secara sederhana dapat dikatakan Ajeg Bali berarti Bali yang kukuh, Bali yang tidak goyah atau Bali yang lestari.1

Selanjutnya berbekal "pembenaran" bernama Ajeg Bali inilah tersebar berbagai perdebatan yang berujung pada sebuah tekad bagimana "menjaga" Bali agar tetap kokoh dan kuat menerima berbagai macam pengaruh yang mengancam keutuhan Bali, terutama yang datang dari luar. Tidak hanya itu, Ajeg Bali juga mengandung gerak "pemurnian budaya", yang ingin memilah antara yang "asli" dan yang "luar". Ini tidak hanya karena benda yang "asli" punya nilai komersial yang tinggi, seperti barang antik di artshop, tetapi juga karena manusia yang "asli" bisa diklaim lebih berhak terhadap sumber daya yang ada di Bali (Degung Santikarma, 2003, dalam I Ngurah Suryawan 2007).

Menurut Ngurah Suryawan (2005), Ajeg Bali telah menjadi instrumen untuk menekankan profil etnik eksklusif dari budaya Bali dan agama. Ajeg Bali sebuah konsep yang berdasarkan pada model pascakolonial. Lebih lanjut menurut I Gusti Ngurah Jayati, dkk. (2008), belakangan ini Ajeg Bali telah jauh bergerak tanpa kendali, bahkan mengarah pada pengentalan dan sentimen budaya atau apa yang disebut representasi etnis dan identitas kebalian lewat semangkok bakso. Contoh Bakso Krama Bali (BKB) memberikan sebuah simbolisasi bahwa bakso yang dijual oleh orang luar seperti yang dijual oleh orang Jawa. Kekhasan dan perbedaan yang ingin ditampilkan oleh penjual Bakso Krama Bali (BKB) adalah pada tampilan dan tonjolan yang kental akan nuansa etnisitas dan identitas kebalian. Dengan semboyan anyar dan sukla tentu membawa makna lain dalam kehidupan masyarakat Bali yang pluralis. Istilah anyar digunakan untuk menyebut sesuatu yang masih baru dan belum

1 Baca Nyoman Kutha Ratna, dkk, “Ajeg Bali Ditinjau dari Aspek Kebudayaan,” Denpasar: Laporan Penelitian dalam rangka Akreditasi Program Studi Magister, Kajian Budaya, Fakultas Sastra, Universitas Udayana, 2005). 
pernah digunakan. Anyar dalam konteks makanan, misalnya adalah segala jenis bahan makanan dan bahannya yang digunakan masih baru, baik daging atau bumbu dan sebagainya. Sedangkan sukla berarti suci, bersih, dan bukan sisa.

Pada sisi lain, kota Denpasar misalnya, dalam bidang kependudukan melalui Dinas Kependudukan dan Catatan Sipil, menggulirkan kebijakan strategi menuju kemapanan Bali dalam mengelola urban, dengan memberlakukan persyaratan Kartu Identitas Penduduk Pendatang (KIPP) dan KIPEM (Kartu Identitas Pendatang Musiman) sebagai sarana untuk memfilter pendatang. ${ }^{2}$

Dalam kebijakan ini pemerintah berkolaborasi dengan Desa Adat dan agama, sehingga KIPP dan KIPEM semacam KTP lokal salah satu syarat untuk memilikinya adalah harus mendapat pengakuan dari desa dinas dan dari desa adat. Hal ini menjadi penting dan menarik karena di Bali ada beda fungsi dari desa dinas dan adat. Desa dinas menyangkut data kependudukan di tempat tertentu, sedangkan desa adat menyangkut tanggung jawab krama adat (warga) terhadap desa adat tersebut dalam ruang lingkup kegiatan agama dan kebudayaan. Otomatis tidak semua pendatang bisa masuk kategori krama adat karena pendatang dari luar Bali sudah pasti bukan orang Bali asli, pun juga pada umumnya tidak beragama Hindu.

Dari syarat ini, memungkinkan orang selamanya pendatang meskipun dia ber-KTP lokal Bali. Konteks krama adat ini yang menentukan. Belum lagi misalnya setiap desa adat memiliki aturan sendiri yang kadang kala berbeda dengan desa adat lainnya, di Bali disebut dengan istilah desa kala patratempat, waktu dan konteks-yang berarti antara tempat yang satu dengan tempat yang lainnya bisa saja berbeda. Adanya kisah-kisah razia KIPEM (Kartu Identitas Penduduk Musiman) KTP (Kartu Tanda Penduduk), dan KIPP (Kartu Indentitas Penduduk Pendatang) misal seperti dialami beberapa mahasiswa dari Sidoarjo, Jawa Timur pada malam, 28 Maret 2008. ${ }^{3}$

\footnotetext{
2 Puspayoga, Bali Post, 2004.

3 Burhanuddin, Yuddhis M, Bali yang Hilang, Pendatang Islam dan Etnisitas di Bali, (Yogyakarta: Penerbit Kanisius, 2008).
} 


\section{Teori-teori Penyebab Perubahan}

Mengapa perubahan itu terjadi? Pertama, Menurut Robert Laurer4 perubahan sosial adalah mencakup seluruh aspek kehidupan sosial, karena keseluruhan aspek kehidupan sosial itu terus menerus berubah. Perubahaan itu normal dan berlanjut tetapi menurut arah yang berbeda di berbagai tingkat kehidupan sosial dengan tingkat kecepatan yang berbeda pula. Selanjutnya, menurut Soerjano Soekanto ${ }^{5}$ terjadinya perubahan dalam suatu masyarakat mungkin karena adanya sesuatu yang dianggap sudah tidak lagi memuaskan. Mungkin saja karena ada faktor baru yang lebih memuaskan masyarakat sebagai pengganti faktor yang lama. Mungkin juga masyarakat mengadakan perubahan karena terpaksa demi untuk menyesuaikan suatu faktor dengan faktor-faktor yang lain yang sudah mengalami perubahan terlebih dahulu. Lebih lanjut dikatakan bahwa perubahan tersebut mungkin sumbernya ada yang terletak di dalam masyarakat itu sendiri (misalnya, pertentangan/conflict) dan ada yang letaknya di luar (misalnya, pengaruh kebudayaan masyarakat lain).

Kedua, menurut teori Psikologi Lintas Budaya perubahan terjadi karena manusia adalah makhluk sosial, dalam kehidupan sehari-hari banyak berinteraksi dengan dan pengaruh orang lain. Sepertinya amat sulit membayangkan suatu keberadaan yang tidak melibatkan kontak dengan orang lain. ${ }^{6}$ Dalam interaksinya manusia berjumpa dengan banyak emik, atau perbedaan kultur, yang secara potensial dapat memunculkan permasalahan ketika manusia mencoba menafsirkan alasan yang mendasari atau yang menyebabkan adanya berbagai perbedaan itu. Karena kita semua berada di dalam kebudayaan masing-masing, dengan latar belakang kultural kita sendiri, kita cenderung melihat sesuatu dari kacamata latar belakang tersebut. Sehingga penafsiran kita tentang perilaku orang lain bisa melenceng sangat jauh.

Ketiga, perubahan dalam masyarakat dapat terjadi karena dalam kita beragama telah mengalami pergeseran dari to be (menjadi) ke to have (memiliki). Pengertian to have dalam arti memiliki agama, berbeda dengan to

${ }^{4}$ Robert Laurer, Perspektif Tentang Perubahan Sosial, (Jakarta: Rineka Cipta, 2003).

5 Soerjono Soekanto, Sosiologi: Suatu Pengantar, (Jakarta: Raja Grafindo Persada, 2003).

${ }^{6}$ David Matsumoto, Pengantar Psikologi Lintas Budaya, (Yogyakarta: Pustaka Pelajar, 2004). 
be dalam pengertian menjadi beragama. Yang pertama menekankan hubungan kepemilikan dalam kontesk kebendaan, sedangkan yang kedua mengasumsikan perilaku sesuai dengan ajaran agama (I Nyoman Wijaya, 2004). Walaupun agama itu memang merupakan pernyataan yang absolut, tetapi itu tidak menjadikan agama sebagai absolut, melainkan hanya Tuhan yang absolut, benar dan final bagi manusia dan masyarakat.7 Ini berarti kepercayaan akan kemahakuasaan Tuhan atas segala sesuatu termasuk manusia dan semua aspek kehidupannya mengimplikasikan bahwa kekuasaan, kehendak dan kebenaran Tuhan tidak dapat dibatasi oleh siapa pun dan tidak dapat dibatasi oleh apa pun, termasuk agama yang diyakini dan dianut $^{8}$

Lebih lanjut Paulus Mujiran (2003), mengatakan tiga hal: pertama, agama merupakan sosialisasi pengalaman iman dalam kehidupan sehari-hari. Pengalaman akan Allah tidak mungkin ditangkap sepenuhnya oleh kenyataan agama, juga oleh agama manapun. Agama mempunyai keunikan masingmasing dalam simbol yang sangat terbatas. Tidak ada simbol yang mampu mengungkapkan sepenuhnya kenyataan ilahi dan mampu mengatasi segalanya. Kedua, keyakinan bahwa tidak ada pengalaman keagamaan yang absolut. Masing-masing pribadi membangun relasi dengan yang ilahi dengan caranya sendiri dan unik. Klaim kebenaran absolut tidak pernah menjadi kenyataan dalam ekspresi kontekstualnya. Kebenarannya selalu dinyatakan dengan keterbatasan manusia. Karena itu, kebenaran yang dinyatakan dalam agama-agama harus di-deabsolutisasi, karena kebenaran tersebut secara esensial dipengaruhi oleh faktor-faktor historis, keterbatasan bahasa dan superstruktur sosial budaya. Ketiga, kehidupan bersama agama lain menjadi ajang saling belajar dan melengkapi satu dengan yang lain.

Keempat, menurut teori dekonstruksi. Dekonstruksi berasal dari akar kata de+constructio (latin). Pada umumnya prefik "de" berarti ke bawah, pengurangan, terlepas dari. Constructio berarti bentuk, susunan, hal menyusun, hal mengatur. Jadi dekonstruksi dapat diartikan sebagai pengurangan atau penurunan intensitas bentuk yang sudah tersusun sebagai bentuk

\footnotetext{
7 Paul F. Knitter, No Other Name? A Critical Survey of Christian Atutitudes Toward The World Religions, (New York: Orbis Books, 1985).

8 Sutarno, Di dalam Dunia tetapi tidak dari Dunia: Pemikiran Teologis tentang Pergumulan Gereja dalam Masyarakat Indonesia yang Majemuk, (Jakarta: BPK Gunung Mulia, 2004).
} 
yang baku. ${ }^{9}$ Dalam dekonstruksi dilakukan semacam pembongkaran, tetapi tujuan akhir yang hendak dicapai adalah penyusunan kembali ke dalam tatanan, dan tatanan yang masih signifikan, sesuai dengan hakikat objek sehingga aspek-aspek yang dianalisis dapat dimanfaatkan semaksimal mungkin.

Dalam teori kontemporer dekonstruksi, sering diartikan sebagai pembongkaran, pelucutan, penghancuran, penolakan dan berbagai istilah dalam kaitannya dengan penyempurnaan arti semula. Dalam mendekonstruksi dilakukan pengurangan intensitas oposisi biner, sehingga unsur-unsur yang dominan tidak selalu mendominasi unsur-unsur yang lain. Sebaliknya unsurunsur semula selalu terlupakan, terdegrasikan dan termarginalisasikan seperti kelompok minoritas, kelompok yang lemah dapat diberikan perhatiaan yang memadai bahwa secara seimbang dan proposional. ${ }^{10}$

Dari keempat teori di atas, didapat beberapa hal penting yang menyebabkan suatu perubahan dalam masyarakat. Pertama, teori perubahan sosial, yakni adanya sesuatu yang tidak lagi memuaskan, bahkan karena konflik. Kedua, psikologi lintas budaya, manusia dalam interaksinya bersifat etnosentrisme yang menghasilkan stereotip tentang orang-orang berasal dari budaya lain. Ketiga, teologi pluralitas agama, adanya pergerseran dari to be (menjadi) menjadi to have (milik) dalam beragama. Keempat, teori dekonstruksi, pengurangan atau penurunan intensitas bentuk yang sudah tersusun sebagai bentuk yang baku.

Dari beberapa penyebab suatu perubahan dalam masyarakat tersebut, Peneliti tertarik untuk melakukan penelitian terhadap perubahan paradigma di Bali (nyama menjadi jelema) yang berfokus pada kearifan lokal Bali. Kearifan lokal yang dimaksud adalah ciri-ciri kebudayaan yang dimiliki oleh suatu masyarakat/bangsa sebagai hasil pengalaman mereka di masa lampau (Poespowardojo, 1986 dalam IBG Yudha Triguna, 2008). Dengan sifat-sifat yang hakiki seperti: Pertama, mampu bertahan terhadap budaya luar. Kedua, mempunyai kemampuan mengakomodasi unsur-unsur budaya luar. Ketiga, mempunyai kemampuan mengintegrasi budaya luar. Keempat, mampu

\footnotetext{
${ }^{9}$ Nyoman Kutha Ratna, dkk., "Ajeg Bali ...”

10 Jacques Derrida, Dekonstruksi Spiritual Merayakan dengan Wajah Spiritual, terj. Firmansyah Agus, (Yogyakarta: Jala Sutera, 2002).
} 
mengendalikan dan memberikan arah pada perkembangan budaya sendiri, sehingga fungsi yang dapat dilaksanakan oleh kearifan lokal menjadi sangat luas dan beragam. Salah satu kearifan lokal Bali yang dikemukakan disini adalah budaya menyama braya. Kearifan lokal dapat berarti wujud budaya yang dimiliki oleh masyarakat yang hidup dan berkembang serta memiliki kemampuan bertahan terhadap budaya luar, mengakomodasi, mengintegrasi, mengendalikan pengaruh budaya luar, serta mampu memberi arah pada perkembagan budaya yang ada.

\section{E. Kembalikan Bali-ku, Gugat Pendatang}

Ketika Bali akan dikembalikan lagi ke budaya dan agama Bali, maka ada persoalan klasik yang muncul. Di Bali saat ini sudah banyak berdiri masjid dan gereja-gereja dengan arsitektur gaya Bali, pemeluknya juga banyak orang Bali. Banyak panti asuhan dan lembaga sosial mengatasnamakan agama tertentu. Mengangkat derajat orang-orang lemah, dididik dan diberi makan. Sikap hidup mereka sudah sesuai dengan Tri Hita Karana, sebagaimana umat Hindu lakukan, tindakan sosial mereka seperti umat Hindu, hanya label luarnya yang berbeda. Umat Kristen gencar membangun panti asuhan, umat Muslim gencar membantu temannya yang berdagang. Kondisi semacam itu menyadarkan orang Bali, bahwa mereka sekarang tidak mono-culture dan mono-religion. Sudah ada saudara yang datang ke tempat mereka, bahkan sudah menguasai beberapa sektor penting di tanah leluhur mereka. Banyak orang Bali yang terdesak, susah mencari pekerjaan di tanah mereka sendiri. Susah mendapatkan makanan di tanah leluhur mereka sendiri. Pendatang sudah menguasai tanah leluhur, orang Bali meradang kelaparan.

Keadaan tersebut membangkitkan semangat patriotisme primordial sehingga muncul gagasan: Bali adalah milik orang Bali, Bali harus dijaga, kembali ke budaya dan agama Bali. Istilah tersebut kemudian dikenal dengan sebutan Ajeg Bali. Jadi Ajeg Bali adalah mengembalikan Bali kepada fitrahnya. Bali harus mencerminkan budaya dan agama Bali. Untuk itu semua harus diusahakan melalui lambaga tradisional seperti banjar, desa adat (pekraman), subak, sekaa (perkumpulan) dan dadia (klen). Keterikatan masyarakat Bali terhadap lembaga-lembaga tradisional tersebut akan berfungsi secara struktural sebagai ketahanan budaya Bali. Menurut Geertz, lambaga tradisional seperti desa adat dianggap sebagai benteng terakhir dari ketahanan budaya Bali. 
Meskipun demikian, perlu dipahami bahwa ketahanan budaya Bali masih memiliki kelamahan dari tiga aspek: pertama aspek struktural, secara fisik aspek ini berkaitan dengan penguasaan lahan tanah sebagai penyangga budaya, sebagaimana sudah disinggung sebelumnya bahwa banyak tanah di Bali sudah berubah fungsi dari pertanian ke industri pariwisata. Kedua, aspek fungsional berhubungan dengan melemahnya fungsi bahasa dan sastra Bali sebagai unsur media kebudayaan. Banyak generasi muda saat ini tidak bisa berbicara bahasa Bali asli, sebaliknya bahasa pop yang justru berkembang. Ketiga, aspek prosesual. Meskipun dengan rapinya media dan masyarakat Bali mampu meredam konflik yang pernah muncul, namun saat masalah tersebut sudah terakumulasi dan muncul di permukaan yang lebih lebar, maka akan terjadi ancaman yang disebut disintegrasi oleh permasalahan primordialisme.

Masyarakat dan kebudayaan Bali tidak bisa lepas dari perubahan di zaman globalisasi. Orang Bali saat ini cenderung mengadopsi kebudayaan modern. Pada sisi yang lain, orang Bali berada pada persimpangan jalan, karena mereka sedang menggiatkan desa adat. Dengan kata lain, orang Bali berdiri pada pijakan yang berbeda. Kaki kanan terikat pada kekuatan tradisi, sedangkan kaki kiri menganut sistem nilai dari luar. Fenomena paradoks semacam ini disebut sebagai countertrend terhadap pengaruh kebudayaan global atau budaya asing.

Jadi apa yang sesungguhnya sedang diperjuangkan oleh orang Bali? Di balik pertanyaan itu, sesungguhnya menyimpan kesedihan yang mendalam akibat lunturnya identitas kebalian. Di Kuta jarang ditemui bangunan yang mencirikan kebalian, sebaliknya semua bangunan ruko berkiblat ke baratbaratan. Seharusnya Kuta-Legian dibangun sesuai dengan nilai-nilai lokal yang ada, sehingga pendatang yang datang di tempat ini akan melihat Bali di Kuta dan Legian, sebaliknya saat ini kesan itu tidak nampak, sangat minim. Di sepanjang jalan Legian, saat ini artshop-artshop sudah banyak dikuasai oleh pendatang, meskipun penguasaan tersebut bersifat sementara. Penduduk setempat tergusur ke belakang dan hanya menjadi penonton di teather miliknya sendiri.

Selain pudarnya salah satu aset bernilai yang namanya kultural dan serbuan pendatang, apa yang mereka rasakan berkurang atau bergeser salah satunya adalah adat. Seorang warga menyatakan, "kita sudah kehilangan 
kekuatan adat, dahulu ada tempat-tempat warga berkumpul di warung atau bale banjar, sekarang tidak lagi. Mungkin ini masih ada tetapi di luar Denpasar". Kondisi kota Denpasar sudah bergeser ke iklim industri pariwisata, lahan tempat berkumpul semakin menyempit, berganti fungsi sebagai toko atau tempat kos.

Potret kecil Legian ini merupakan salah satu persoalan yang sedang dialami masyarakat Bali, selain persoalan struktural, perebutan kekuasaan dan ekonomi. Secara umum dapat dikatakan, bahwa pesatnya industri pariwisata Bali membawa persoalan sosial, budaya dan agama. Persoalan sosial, misalnya banyaknya pendatang yang mengais rejeki di Pulau ini tidak terbendung lagi, akibatnya masyarakat Bali harus mampu bersaing dengan pendatang yang pada umumnya memiliki modal dan kemampuan. Begitu juga pada persoalan budaya, setiap pendatang yang datang di Bali membawa kebudayaan mereka dari tempat mereka masing-masing, ketika mereka menikah dengan penduduk setempat, maka mau tidak mau budaya asing ini mulai diperkenalkan, hal ini akan mengganggu budaya setempat. Dalam persoalan agama, oleh karena setiap warga negara dijamin oleh Undang-Undang tentang kebebasan dalam melakukan agama atau kepercayaannya, maka orang yang datang di Bali juga melaksanakan keyakinan mereka. Akibatnya, saat ini sudah banyak bangunan masjid dan gereja di seluruh Bali, tempat sembahyang selain pura.

Persosalan stuktural di atas menyebabkan Bali saat ini terjadi semacam ketegangan relasi antara "kita" penduduk lokal dengan "mereka" para pendatang. Ketegangan ini merupakan aksi-reaksi dari situasi yang berkembang di Bali. Sebagai contoh, ketika penulis belanja hasil kerajinan masyarakat Bali bersama dengan orang setempat, pertama kami menggunakan bahasa Indonesia, lukisan itu dijual dengan harga yang cukup mahal. Tetapi ketika teman tadi menggunakan bahasa daerah, harga lukisan menjadi murah, dengan mengatakan "kaden sing nak Bali" (saya kira Anda bukan orang Bali). Dari peristiwa tersebut dapat dikatakan bahwa, pengelompokkan "kita" dan "mereka" masih sangat terasa.

Dalam usaha menjaga keaslian budaya dan agama Bali dan dalam rangka membatasi Bali dari pendatang maka pemerintah Denpasar melakukan sweeping terhadap semua pendatang. Pada prinsipnya semua pendatang 
harus memiliki ijin tinggal di Bali. Oleh karena itu pemerintah Denpasar memberlakukan beberapa aturan, aturan ini dikenakan, khususnya bagi para pendatang. Tujuannya adalah untuk menegakkan Ajeg Bali meliputi beberapa kegiatan yang menyangkut beberapa aspek kehidupan masyarakat yang akan dan yang sudah tinggal di Bali. Usaha-usaha tersebut antara lain, tertib administrasi kependudukan. Dengan diterbitkannya Surat Kesepakatan Bersama antara Gubernur dengan Bupati/ Walikota se Bali. No. 153 Th. 2003.

Tentang Pelaksanaan Tertib Administrasi Kependudukan Bali. Aturan tersebut mengatur setiap pendatang harus memiliki (KIPP) yaitu Kartu Indentitas Penduduk Pendatang (KIPP) dan Kartu Identitas Pendatang Musiman (KIPEM). Kartu ini diberikan kepada masayrakat yang sering datang ke Bali untuk beberapa waktu, sementara saja, dengan kartu ini pendatang diijinkan untuk tinggal sementara. Dalam pelaksanaannya, pemerintah kota bekerjasama dengan Desa Adat dan tokoh Agama, sehingga setiap pendatang di Bali, untuk mendapatkan KIPP atau KIPEM wajib mendapatkan rekomendasi dari Desa Adat dan Desa Dinas. Dalam hal pelaksanaan operasional pemerintah bekerjasama dengan pecalang. Tujuan diterbitkannya KIPP dan KIPEM adalah untuk membatasi pendatang liar. Dengan kata lain, pemerintah ingin memberi kesempatan kepada penduduk lokal untuk mendapatkan kesempatan yang lebih besar dalam pengelolaan sumber-sumber ekonomi, politik dan budaya. Selanjutnya kegiatan ini dikenal dengan sebutan Ajeg Bali.

Dalam bidang keagamaan, masyarakat Bali sudah mulai menampakkan simbol-simbol keagamaannya dengan cara mengadopsi model yang sudah ada pada agama lain, terutama dalam pemberian salam. Beberapa media elektronik seperti radio dan televisi lokal melalui social-advertisment berusaha untuk menampilkan Ajeg Bali dengan mengatakan "om swastiastu", dengan cara ini sesama orang Bali-Hindu merasa terikat secara emosional sebagai "kita". Begitu juga dalam arsitektur bangunan rumah ibadah nonpura, yang dahulu ornamen yang mencirikan kebalian digunakan sebagai simbol bahwa rumah ibadah itu menghormati budaya Bali, akan tetapi saat ini bangunan, terutama rumah ibadah selain pura yang memiliki ornamen kebalian kembali digugat atau dipertanyakan. Ini merupakan bentuk resis- 
tensi orang Bali yang mengklaim Bali identik dengan hinduisme dengan seperangkat kerasnya, termasuk arsitektur bangunannya.

Meningkatnya permasalahan sosial-ekonomi-keagamaan yang terkait dengan keberadaan pendatang menyebabkan masyarakat Bali bereaksi. Dahulu orang Bali menyebut orang Jawa "nak Jawa" artinya saudara dari Jawa. Keadaan tersebut secara perlahan namun pasti membawa perubahan sikap masyarakat Bali terhadap para pendatang. Bibir yang dahulu digunakan untuk memberi senyum dan salam, sekarang digunakan untuk mengumpat dan mencaci maki. Hati yang dahulu terbuka sekarang menjadi tertutup. Dahulu orang Bali menyebut pendatang yang berasal dari Jawa "nak Jawa" atau "nyama Jawa" artinya saudara dari Jawa. Tetapi sekarang sebutan itu mengalami pergeseran menjadi "jelema Jawa" artinya orang Jawa. ${ }^{11}$

Jelema merupakan istilah yang patut digunakan untuk menyebut makhluk yang belum sempurna. Pergeseran dari nyama ke jelema menandakan perubahan cara pandang dan penerimaan keberadaan orang Bali terhadap orang Jawa. Nyama menunjukkan kedekatan hubungan, sedangkan jelema menunjukkan kejauhan hubungan. Hal-hal ini menunjukkan bahwa sudah ada kesadaran kelas di dalam diri orang Bali, kesadaran tersebut disebabkan adanya ancaman yang datangnya dari luar. Pada akhirnya, semangat etnisitas masyarakat Bali tergugah dan mengarah pada kristalisasi dan atau sentimen budaya yang disebut representasi etnis dan identitas kebalian melalui istilah atau nama-nama yang digunakan oleh masyarakat. Contoh, penggunaan nama "Bakso Krama Bali" merupakan perwujudan dari program Koperasi Krama Bali (KKB). KKB merupakan sebuah lembaga yang bergerak di bidang enterprenuership ekonomi bagi masyarakat yang hanya memiliki modal usaha terbatas. Begitu juga ketika ada seorang anak akan membeli bakso dengan memanggil penjual bakso "mas beli bakso", ketika ada seorang lakilaki datang seraya mengatakan, "beli bakso" bukan mas, tapi bli" (bli merupakan istilah untuk memanggil mas, orang Bali). Dari dua contoh di atas menunjukkan adanya tampilan yang lebih menonjolkan nuansa khas "keBali-annya". 2009.

11 Wayan Damayana, "Menyama Braya Dalam Dinamika Masyarakat Bali”, proposal disertasi, 
Perubahan sikap yang ditunjukkan oleh masyarakat Bali tersebut sebenarnya merupakan bentuk resistensi budaya yang lebih disebabkan oleh hegemoni pendatang yang lebih dominan dari pada penduduk asli. Oleh karena itu, tidak mustahil jika terjadi perbedaan konsep mengenai menyama braya antara penduduk asli Bali terutama yang tinggal di desa dengan konsep menyama braya penduduk Bali pendatang.

Setiap kali ada upacara di pura-pura, maka kaum pendatang dari luar Bali menggunakan kesempatan itu untuk berdagang. Ini yang dimaksudkan dengan peluang pasar. Fenomena yang sering terjadi adalah pelaksanaan upacara di tingkat Banjar lebih banyak mengedapankan glamournya daripada seremonialnya. Kondisi tersebut semakin diperlemah dengan rendahnya tingkat solidaritas dan interaksi sosial antar umat. Pertemuan sebagai ajang komunikasi dan pendekatan diri tidak terjadi antar umat ketika berada di pura, satu dengan yang lain seolah-olah tidak saling mengenal dan menyapa.

\section{F. Kesimpulan}

Wacana Ajeg Bali, saat ini sudah menjadi trend mark masyarakat Bali, mulai dari anak-anak sampai orang dewasa, bahkan dari kalangan masyarakat biasa sampai birokrat. Mereka sering manggunakan istilah Ajeg Bali dalam peristiwa-peristiwa tertentu. Misalnya, Ikatan Dokter Indonesia (IDI) cabang Bali pada saat merayakan hari ulang tahunnya menggunakan tema "Kesehatan dengan Ajeg Bali". Pada satu sisi giatnya penduduk Bali kembali kebudayaan nenek moyang merupakan hal yang positif, akan tetapi pada sisi yang lain, wacana Ajeg Bali bergerak tanpa kendali dan mengarah kepada sentimen budaya. Dalam hal ini, Ajeg Bali sudah menjelma menjadi doktrin yang seolah-olah sebagai ideologi tunggal di tengah-tengah hegemoni budaya dan suku yang ada.

Dalam perkembangannya, Ajeg Bali mengalami pergeseran makna dan masuk ke dalam ruang lingkup kehidupan sosial masyarakat Bali, hal ini terutama berkaitan dengan kondisi akhir-akhir ini, melalui peristiwa bom yang terjadi di Legian dan Kuta. Bagi masyarakat Bali ini merupakan peristiwa yang menyakitkan dan memalukan, sekaligus menyadarkan mereka dari tidur panjangnya. Melalui peristiwa itu ikatan primordial mereka 
semakin kuat, bahwa Bali bukan milik pendatang! Ajeg Bali harus ditegakkan! Ngurah Suryawan menyatakan Ajeg Bali sudah menjelma menjadi ideologi yang hegemonik dan menimbulkan perbedaan "orang Bali" dan "bukan Bali". ${ }^{12}$ Sementara itu, Kiwi menyatakan Ajeg Bali merupakan "commitment to the development of Balinese culture to keep social harmony on the island of Bali". ${ }^{13}$ Pandangan ini tentu saja tidak mewakili pandangan dan konsep masyarakat Bali khususnya mengenai Ajeg Bali.

Untuk membangun sebuah konsep ekonomi baru dengan tujuan merebut kembali pangsa ekonomi masyarakat Bali yang kalah bersaing dengan pendatang, maka konsep Ajeg Bali dijadikan sebagai dasar. Selanjutnya muncul sebuah program yang dikenal dengan sebutan "Koperasi Krama Bali" (KKB), yang berdiri sejak tanggal 22 Mei 2002".14 KKB didirikan dengan tujuan untuk membangkitkan ekonomi rakyat Bali, dengan demikian pemberdayaan Ajeg Bali semakin kuat. Program kerja yang dimiliki oleh KKB selain memberikan pelatihan-pelatihan secara gratis bagaimana membuat makanan khas Bali, juga memberikan pinjaman modal pada karma, warga Hindu Bali. Setiap tempat usaha yang dibina oleh KKB akan dipasang spanduk bertuliskan, "Binaan Koperasi Krama Bali".

Menguatnya perubahan sikap masyarakat Bali-Hindu terhadap para pendatang yang muncul melalui identitas ke-Bali-an juga dipengaruhi oleh tokoh yang mencetuskan Ajeg Bali, yaitu Made Mangku Pastika dengan ungkapan khasnya yang sangat menyentuh, "Orang Bali kini seperti memberi senjata kepada orang luar (pendatang) untuk membunuh orang Hindu Bali sendiri". Sedangkan Ida Pedanda Made Gunung menyatakan, "Orang Bali jual tanah untuk beli bakso, sedangkan orang luar jual bakso untuk beli tanah di Bali."15

Kentalnya entitas dan identitas ke-Bali-an merupakan usaha penguatan legalisasi dari politik identitas masyarakat Bali, dan sekaligus merupakan

\footnotetext{
12 I Ngurah Suryawan, Bali: Narasi Dalam Kuasa Politik dan Kekerasan di Bali, (Yogyakarta: Penerbit Ombak, 2005), h. 235.

13 Kiwi Freelancer, "Ajeg Bali”, http://www.bali-dreamland.com/2008.09/ajeg-bali.html., submitted on Tuesday, 30 September 2008, diakses tanggal 20 Januari 2011.

14 I Ngurah Suryawan, Bali: Narasi Dalam Kuasa Politik dan Kekerasan di Bali, (Yogyakarta: Penerbit Ombak, 2005), h. 3. 2010).

15 Nengah Bawa Atmadja, Ajeg Bali, Gerakan, Identitas dan Globalisasi, (Yogyakarta: LkiS,
} 
bentuk resistensi masyarakat Bali dari ancaman yang datangnya dari luar. Jika Ajeg Bali akan digiatkan, maka pertanyaannya adalah dapatkah generasi Bali-Hindu saat ini memurnikan kembali konsep Ajeg Bali seperti dahulu? Permasalahannya adalah Bali sekarang sudah mengalami perubahan yang sangat signifikan apabila dibandingkan dengan 10 tahun yang lalu. Dapatkan Ajeg Bali dibangun kembali, jika dapat bagian manakah yang akan dibangun, agama, budaya atau ekonominya?[w] 


\section{BIBLIOGRAFI}

Atmadja, Nengah Bawa, Ajeg Bali, Gerakan, Identitas dan Globalisasi, Yogyakarta: LKiS, 2010.

Bali Post Team, Ajeg Bali Sebuah Cita-cita, Denpasar: Penerbit Bali Post, 2004.

Burhanuddin, Yuddhis M, Bali yang Hilang, Pendatang Islam dan Etnisitas di Bali, Yogyakarta: Penerbit Kanisius, 2008.

Damayana, Wayan, "Menyama Braya dalam Dinamika Masyarakat Bali”, 2009.

Darma Putra, I Nyoman (ed.), Bali Menuju Jagaditha: Aneka Perspektif, Denpasar: Pustaka Bali Post, 2004.

Derrida, Jacques, Dekonstruksi Spiritual Merayakan dengan Wajah Spiritual, terj. Firmansyah Agus, Yogyakarta: Jala Sutera, 2002.

Hick, Jhon dan Knitter, Paul F, Mitos Keunikan Agama Kristen, Jakarta: BPK Gunung Mulia, 2001.

Jayanti Ngurah, I Gusti, dkk, "Representasi Etnis dan Identitas Kebalian: Mempertanyakan Sentimen Sosial," Jurnal Kajian Budaya Vol. 5 No. 1, Januari 2008, Denpasar: Program S2 dan S3 Kajian Budaya Universitas Udayana, 2008.

Knitter, Paul F., Satu Bumi Banyak Agama: Dialog Multi-agama dan Tanggungjawab Global, diterjemahan oleh Nico A. Likumahuwa, Jakarta: BPK Gunung Mulia, 2003.

No Other Name? A Critical Survey of Christian Atutitudes Toward The World Religions, New York: Orbis Books, 1985.

Koetjaraningrat, Kebudayaan, Mentalitas dan Pembangunan, Jakarta: Gramedia Pustaka Utama, 2002.

Kutha, Ratrna, Nyoman, dkk., "Ajeg Bali Ditinjau Dari Aspek Kebudayaan," laporan penelitian dalam rangka akreditasi Program Studi Magister, Kajian Budaya, Fakultas Sastra, Universitas Udayana, Denpasar: Fakultas Sastra Universitas Udayana, 2005.

Laurer, Robert, Perspektif tentang Perubahan Sosial, Jakarta: Rineka cipta, 2003.

Lestawi, I Nengah, Hukum Adat, Surabaya: Paramita, 1999.

Walisongo, Volume 21, Nomor 2, November 2013 
Matsumoto, David, Pengantar Psikologi Lintas Budaya. Yogyakarta: Pustaka Pelajar, 2004.

Ngurah Suryawan, Bali: Narasi Dalam Kuasa Politik dan Kekerasan di Bali, Yogyakarta: Penerbit Ombak, 2005.

Pitana, IGde (ed), Dinamika Masyarakat dan Kebudayaab Bali, Denpasar: Penerbit Bali Post, 1994.

Sairin, Sjafri, Perubahan Sosial Masyarakat Indonesia "Perspektif Antropolog, Yogyakarta: Pustaka Pelajar, 2002.

Setia, Putu, Bali yang Meradang, Denpasar: Pustaka Manikgeni, 2006.

Shadily, Hassan, Sosiologi untuk Masyarakat Indonesia, Jakarta: Penerbit Rineka Cipta, 1993.

Soekanto, Soerjono, Sosiologi Suatu Pengantar, Jakarta: Raja Grafindo Persada, 2003.

Soethama, GDE Aryantha, Bolak-Balik Bali, Denpasar: Arti Foundation, 2006.

Suhardana, KM., Memahami Kesejagatan Agama Hindu, Denpasar: Panakomi Publishing, 2006. Panca Sradha, Lima Keyakinan Umat Hindu, Surabaya: Paramita, 2009.

Suparta, I Nyoman Kanduk, Sigug: Karakter Bali Modern dan Pudarnya Identitas Orang Bali, Denpasar: Pustaka Bali Post, 2006.

Sutarno, Di dalam Dunia tetapi tidak dari Dunia: Pemikiran Teologis tentang Pergumulan Gereja dalam Masyarakat Indonesia Yang Majemul, Jakarta: BPK Gunung Mulia, 2004.

Triguna Yudha IBG (ed.), Kebudayaan dan Modal Budaya Bali dalam Teropong Lokal, Nasional Global, Denpasar: Widya Darma, 2008.

\section{Internet:}

Kiwi freelancer, "Ajeg Bali", http://www.bali-dreamland.com/2008.09/ajegbali.html., submitted on Tuesday, 30 September 2008, diakses Selasa, 20 Januari 2011.

Muhajir, Anton, Bali, Hindu dan Islam, http://www.balebengong.net/ budaya/2008/09/21/akulturasi-bali-hindu-dan-islam-di-pegayaman.html, 2008.

Muhajir, Anton, Menyama Braya di Hari Natal, http://www.balebengong.net/ kabar-anyar/2008/12/25/menyama-braya-di-hari-natal.html, diakses pada 25 Desember 2008. 